\title{
The distinction awards system in England and Wales 1980
}

\author{
PETER BRUGGEN， STANFORD BOURNE
}

\begin{abstract}
New details are available for the distribution of distinction awards in 1980. Other data are tabulated for comparison with previous years. ${ }^{1-6}$ There are no impressive changes; in fact, the bias, which we have described before, persists. We have again used our scoring of awards points per 100 consultants to summarise complex data.* An A + award represents four separate acts of promotion and is, in money, worth more than four times as much as a C award. Similarly, pro rata, for A and $B$ awards. An A + award is $£ 18100$, an $A$ award is $£ 13950$, a $B$ award is $£ 8350$, and a $C$ award is $£ 3720$.
\end{abstract}

\section{Distribution}

The four Thames Regions (4649 consultants) have $59 \cdot 8$ awards points per 100 consultants; the provinces (8594 consultants) have 50.9 points. In the provinces $60 \%$ of consultants are in contract with regional health authorities (RHAs) compared with only $45 \%$ in London and this pulls the average score down. Area health authority (teaching) (AHA(T)) consultants score much higher. Consultants with RHA contracts do a little better in the provinces (38.2 points per hundred) compared with London consultants with RHA contracts ( 36.7 points per hundred). No other figures are available this year for detailed regional comparisons but it is official policy to even things out geographically - an acknowledged influence on distribution of awards.

Since 1979 more specialties are defined separately rather than being included in broader headings. At the risk of slight errors, we have reassembled these subgroups into the former headings to compare scores since 1974 (table I). For the distribution of new awards and of advisory committee members the data are still issued under the pre-1979 groupings.

The gap of about 44 points per 100 consultants, between the top and bottom bands of seven or eight specialties, was reduced by about 1.5 points last year and by about 10 points since 1974 . A few large fluctuations in award points scores in small specialties may represent only one or two retirements or new awards. Plastic surgeons and paediatricians seem to have lost ground. Community physicians are slowly picking up more of the awards put into the pool for them in 1974. The main shape of the table has not changed.

We now have figures for the separate specialties at the postgraduate teaching hospitals (PGTHs); and also for the over-60s in the separate specialties at PGTHs, AHAs(T), and RHAs. At the PGTHs there is not the same disparity between specialties that exists elsewhere (tables I and II). The special advisory committee for PGTHs and, possibly by the same token, the influence of favourable preconceptions, seem to promote recognition of

* A + award $=4$ points; $A$ award $=3$ points; $B$ award $=2$ points; $C$ award $=$ 1 point.

Adolescent Unit, Hill End Hospital, St Albans, and The Tavistock Clinic, London NW3 $5 B A$

PETER BRUGGEN, DCH, FRCPSYCH, consultant psychiatrist

The Tavistock Clinic

STANFORD BOURNE, MRCP, FRCPSYCH, consultant psychotherapist groups who do badly elsewhere. For instance, 80 consultants at the Bethlem Royal and Maudsley Hospitals, the PGTH for psychiatry, scored 98.8 awards points per cent (including five $\mathrm{A}+$ awards and six A awards), slightly above the average for all PGTHs. Outside the PGTHs, the disparity between specialties at retirement increases steeply at AHAs(T) and RHAs (table II).

\section{AGE GROUP}

In table III we refer mainly to the figures for men and discuss those for women separately. No one under 50 has an A + award; no one under 45 an $\mathrm{A}$ award; no one under 40 a $\mathrm{B}$ award; and there are no awards at all to people under 35 . There are only nine $\mathrm{C}$ awards to men under 40 and they are only one-tenth as common as an $\mathrm{A}+$ award to people over 60 .

$A+$ awards are held by $5.3 \%$ of men aged 60 to 64 or $3.5 \%$ of men aged 55 to 64 . Among men retiring over 60 , well over one in 20 has an $\mathrm{A}+$ award, about one in ten in $\operatorname{AHAs}(\mathrm{T})$, and at least one in five at PGTHs. In RHAs only one consultant in 50 or 60 will have an $\mathrm{A}+$ award on retirement.

Among men over 60 , one in six has an $\mathrm{A}$ award or better. An $\mathrm{A}$ or $\mathrm{A}+$ award is attained by about $6 \%$ of men at RHAs, by about $30 \%$ at AHAs(T), and by about $45 \%$ of men over 60 at PGTHs.

The age scatter is wider for $\mathrm{B}$ and $\mathrm{C}$ awards. More than onethird of all consultants have at least a $\mathrm{B}$ award at retirement and three out of four men have at least a $C$ award. At PGTHs, over $80 \%$ of consultants will reach at least a B award; in the AHAs(T), over $50 \%$; in the RHAs, about $23 \%$.

\section{TEACHING AND NON-TEACHING HOSPITALS}

Since 1974 the figures for undergraduate teaching hospitals have been lost in the AHAs(T) figures but, at last, we have some fresh figures for the PGTHs (table IV). These are illuminating since the undergraduate teaching hospitals presumably score between the PGTHs (97.4 points per cent) and the AHAs(T) (74.6 points per cent).

RHA, AHA(T), and PGTH consultants all score around $20 \%$ with $\mathrm{C}$ awards, but presumably these are acquired 10 to 20 years earlier, where men are destined for higher awards, mainly at the teaching hospitals. A + awards are six times as common in $\operatorname{AHA}(\mathrm{T})(1.8 \%)$ as in RHA consultants $(0.3 \%)$; and 12 times as common in PGTH $(3.5 \%)$ as in RHA consultants $(0.3 \%)$. A awards seem to be about five or six times as common in teaching as in non-teaching hospitals and $\mathrm{B}$ awards four times as common.

An A + or A award is a perquisite for nearly half the teaching hospital men consultants approaching retirement, possibly even more in the favoured specialties. The widespread assumption that these scarce awards are allocated only to consultants of extraordinary achievement is evidently false so far as teaching hospitals are concerned.

\section{WOMEN}

Women have to be older than'men to get their awards. They score $19 \cdot 7$ awards points per 100 consultants, about one-third of 
TABLE I-Distribution of distinction awards to specialties, England and Wales 1980

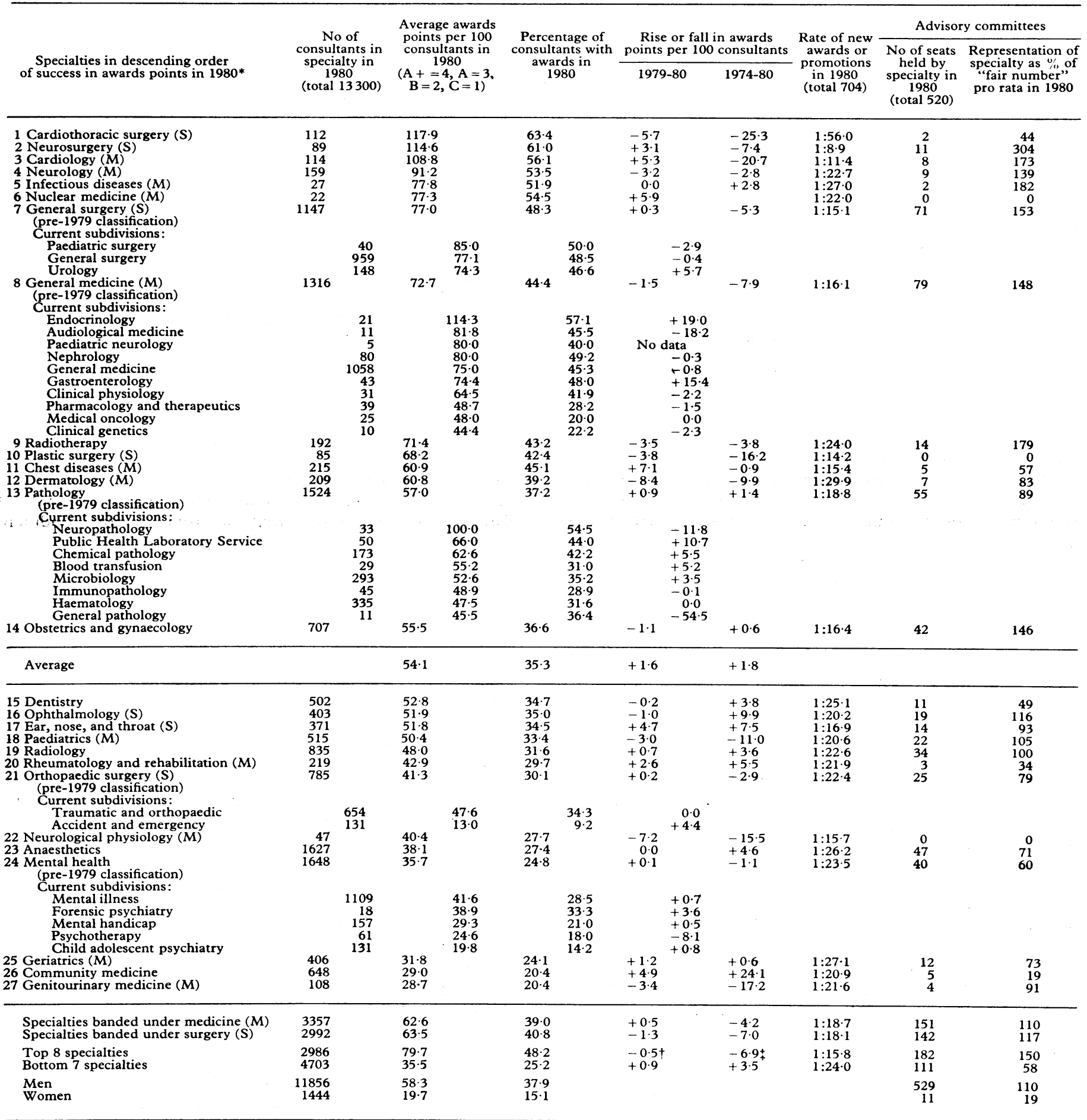

* $M=$ banded under medicine. $S=$ banded under surgery.

t or 0.4 if nuclear medicine is excluded-that is, if exactly the same specialties as last year are compared.

$\ddagger$ or -6.8 if nuclear medicine is excluded-that is, if exactly the same specialties as last year are compared.

the $58 \cdot 3$ points per 100 men. The present generation of women consultants were the girls who had to compete much harder than boys to enter medical school; and for whom it was then even harder to become consultants. It is inconceivable that women consultants are of generally inferior calibre even if, for many, ambition and career were eroded by family commitments, making it more difficult for them to achieve their full potential ability in our professions.

An examination of the higher awards distribution and committee membership exposes figures that require different explanations. Only one woman in England and Wales has an A + award, compared with 119 men. She is one of 308 women aged 55 to $64(0.3 \%)$ compared with $109 \mathrm{~A}+$ award holders among 3089 men $(3.5 \%)$ of the same age. As we know that about one in ten men consultants over 60 in AHAs(T) will have an $\mathrm{A}+$ award and about one in five at PGTHs, we cannot believe that anyone will seriously contend that there is only one woman doctor in the country who can attain this relatively commonplace level of distinction. It is surely inescapable that we are observing the universal tendency for self-regarding groups to allocate the 
TABLE II-Distribution of awards to consultants aged over 60: high-and lowscoring specialties compared, England and Wales 1980

\begin{tabular}{lccc}
\hline & \multicolumn{2}{c}{ Points per 100 consultants* } & \multirow{2}{*}{$\begin{array}{c}\text { Points score ratio: } \\
\text { top 8/bottom } 7 \\
\text { specialties }\end{array}$} \\
\cline { 2 - 3 } & Top 8 specialties & Bottom 7 specialties & \\
\hline PGTH & 250.0 & 241.7 & 1.03 \\
AHA(T) & 219.7 & 119.2 & 1.84 \\
RHA & 147.7 & 64.0 & 2.31
\end{tabular}

$* A+=4$ points; $A=3$ points $; B=2$ points; $C=1$ point.

prizes to people as much like themselves as possible. (And few of us would be free of the tendency.)

\section{NEW AWARDS}

There were 704 new awards (including promotions) in 1980, received by one in about 19 consultants. This raised the proportion of consultants with awards from $34.3 \%$ in 1979 to $35.3 \%$ in 1980. There is the usual inevitable variation in the new award rate, especially in smaller specialties where a few awards affect the score more obviously. The top eight specialties taken together (with 2986 consultants) had awards for one in about 16; the bottom seven specialties (with 4703 consultants) had awards for one in 24. This top group is also represented on advisory committees about three times as strongly, pro rata, as the bottom group. Here we have no separate figures for men and women.
The case of women is even more extreme. There are only 11 women on all the advisory committees, which is one-fifth of the number expected pro rata. There are no women on the top advisory committee and none on 22 of the 30 regional committees. Of course, women score one-third the awards points of men.

Since 1974 the undergraduate teaching hospitals have lost their separate committees with a preferential quota of nominations ${ }^{1}$ but the PGTHs have retained theirs. From available data it is difficult to see clearly whether the teaching hospitals are fairly represented but, scanning the list of names, we have some impression that the teaching hospitals are overrepresented on the higher awards committees-where the main difference in awards lies. For instance, among 22 members of the higher award committee for one region, 18 (including six professors) are listed as principally practising at undergraduate teaching hospitals.

The committees function on the plausible assumption that merit and achievement are self-evident in most cases. Though this could be true for the rare person it could not apply to the ordinary merit needed for most awards. The false premise has led to a system that disregards all that is known of pitfalls in scientific work, where it is otherwise accepted that enthusiastic hard work is no substitute for hard data; and that observer error can make findings worthless.

Clearly, a system of discretionary awards cannot be run like a double-blind trial, but it may be wrong to swing to an abandoned disregard of every lesson available from scientific tradition. Regional advisory committees function almost entirely on the

TABLE III-Distribution of awards analysed by sex and age group, England and Wales 1980

\begin{tabular}{|c|c|c|c|c|c|c|c|c|c|c|c|c|}
\hline & \multirow{2}{*}{$\begin{array}{l}\text { No in } \\
\text { age group }\end{array}$} & \multirow{2}{*}{$\begin{array}{c}\text { Awards points } \\
\text { per } 100 \\
\text { consultants* }\end{array}$} & \multicolumn{2}{|c|}{ All awards } & \multicolumn{2}{|c|}{ A +} & \multicolumn{2}{|c|}{ A } & \multicolumn{2}{|c|}{ B } & \multicolumn{2}{|c|}{ C } \\
\hline & & & No & $\%$ & No & $\because$ & No & $\%$ & No & $\%$ & No & $\because$ \\
\hline $\begin{array}{l}\text { Women: } \\
\text { All ages } \\
\text { Under } 30 \\
30-34 \\
35-39 \\
40-44 \\
45-49 \\
50-54 \\
55-59 \\
60-64 \\
\text { Over } 65\end{array}$ & $\begin{array}{r}1444 \\
0 \\
94 \\
237 \\
301 \\
249 \\
246 \\
220 \\
88 \\
9\end{array}$ & $\begin{array}{r}0 \cdot 0 \\
0 \cdot 0 \\
0 \cdot 0 \\
4 \cdot 0 \\
16 \cdot 5 \\
28 \cdot 7 \\
48 \cdot 2 \\
50 \cdot 0 \\
44 \cdot 4\end{array}$ & $\begin{array}{r}214 \\
0 \\
0 \\
0 \\
12 \\
38 \\
61 \\
74 \\
27 \\
2\end{array}$ & $\begin{array}{r}15 \cdot 1 \\
0 \cdot 0 \\
0 \cdot 0 \\
0 \cdot 0 \\
4 \cdot 0 \\
15 \cdot 3 \\
24 \cdot 8 \\
33 \cdot 6 \\
30 \cdot 7 \\
22 \cdot 2\end{array}$ & $\begin{array}{l}1 \\
0 \\
0 \\
0 \\
0 \\
0 \\
0 \\
0 \\
1 \\
0\end{array}$ & $\begin{array}{l}0 \cdot 07 \\
0 \cdot 0 \\
0 \cdot 0 \\
0 \cdot 0 \\
0 \cdot 0 \\
0 \cdot 0 \\
0 \cdot 0 \\
0 \cdot 0 \\
1 \cdot 1 \\
0.0\end{array}$ & $\begin{array}{r}12 \\
0 \\
0 \\
0 \\
0 \\
0 \\
3 \\
6 \\
3 \\
0\end{array}$ & $\begin{array}{l}0 \cdot 9 \\
0 \cdot 0 \\
0 \cdot 0 \\
0 \cdot 0 \\
0 \cdot 0 \\
0 \cdot 0 \\
1 \cdot 2 \\
2 \cdot 7 \\
3 \cdot 4 \\
0.0\end{array}$ & $\begin{array}{r}37 \\
0 \\
0 \\
0 \\
0 \\
3 \\
4 \\
20 \\
8 \\
2\end{array}$ & $\begin{array}{r}2 \cdot 6 \\
0.0 \\
0.0 \\
0.0 \\
0.0 \\
1.2 \\
1.6 \\
9 \cdot 1 \\
9 \cdot 1 \\
22 \cdot 2\end{array}$ & $\begin{array}{r}164 \\
0 \\
0 \\
0 \\
12 \\
35 \\
54 \\
48 \\
15 \\
0\end{array}$ & $\begin{array}{r}11 \cdot 6 \\
0.0 \\
0.0 \\
0.0 \\
4 \cdot 0 \\
14 \cdot 1 \\
22 \cdot 0 \\
21 \cdot 8 \\
17 \cdot 1 \\
0.0\end{array}$ \\
\hline $\begin{array}{l}\text { Men: } \\
\text { Ali ages } \\
\text { Under } 30 \\
30-34 \\
35-39 \\
40-44 \\
45-49 \\
50-54 \\
55-59 \\
60-64 \\
\text { Over } 65\end{array}$ & $\begin{array}{r}11856 \\
2 \\
524 \\
1846 \\
2317 \\
2128 \\
1841 \\
1723 \\
1366 \\
109\end{array}$ & $\begin{array}{r}0.0 \\
0.0 \\
0.5 \\
14.5 \\
48 \cdot 0 \\
86 \cdot 8 \\
117 \cdot 2 \\
134.3 \\
115 \cdot 6\end{array}$ & $\begin{array}{r}4487 \\
0 \\
0 \\
9 \\
306 \\
831 \\
1070 \\
1200 \\
1020 \\
51\end{array}$ & $\begin{array}{r}37 \cdot 9 \\
0 \cdot 0 \\
0 \cdot 0 \\
0 \cdot 5 \\
13 \cdot 2 \\
39 \cdot 1 \\
58 \cdot 1 \\
69 \cdot 7 \\
74 \cdot 7 \\
46 \cdot 8\end{array}$ & $\begin{array}{r}119 \\
0 \\
0 \\
0 \\
0 \\
0 \\
4 \\
37 \\
72 \\
6\end{array}$ & $\begin{array}{l}1.0 \\
0.0 \\
0.0 \\
0.0 \\
0.0 \\
0.0 \\
0.2 \\
2.2 \\
5.3 \\
5.5\end{array}$ & $\begin{array}{r}424 \\
0 \\
0 \\
0 \\
0 \\
20 \\
74 \\
168 \\
150 \\
12\end{array}$ & $\begin{array}{r}3 \cdot 6 \\
0 \cdot 0 \\
0 \cdot 0 \\
0 \cdot 0 \\
0 \cdot 0 \\
0 \cdot 9 \\
4 \cdot 0 \\
9 \cdot 8 \\
11 \cdot 0 \\
11 \cdot 0\end{array}$ & $\begin{array}{r}1125 \\
0 \\
0 \\
0 \\
30 \\
151 \\
368 \\
372 \\
299 \\
5\end{array}$ & $\begin{array}{r}10 \cdot 3 \\
0 \cdot 0 \\
0 \cdot 0 \\
0 \cdot 0 \\
1 \cdot 3 \\
7 \cdot 1 \\
20 \cdot 0 \\
22 \cdot 0 \\
21.9 \\
4 \cdot 6\end{array}$ & $\begin{array}{r}2719 \\
0 \\
0 \\
9 \\
276 \\
660 \\
624 \\
623 \\
499 \\
28\end{array}$ & $\begin{array}{r}22.9 \\
0.0 \\
0.0 \\
0.3 \\
11.9 \\
31.0 \\
33.9 \\
36.2 \\
36.5 \\
25.7\end{array}$ \\
\hline
\end{tabular}

${ }^{*} \mathrm{~A}+=4$ points $\mathrm{A}=3$ points $\mathrm{B}=2$ points $\mathrm{C}=1$ point.

\section{Advisory committees}

The regional advisory committees are selected at the DHSS from nominations submitted locally by regional committees for hospital medical services. This is in order to allow balance. The aim is for committees to cover most branches of medicine and most hospitals in each region-if possible. Committees would be too big if every subgroup were separately represented but it is the responsibility of each committee (plus the chairman of the system and his administrative team) to ensure that the cases of those consultants not closely represented are examined carefully and estimated fairly. This task they clearly approach conscientiously. Equally clearly, these aims are not realised. The committees remain heavily biased in their composition and the awards are recommended preponderantly to those groups best represented. The top seven specialties are represented nearly three times as strongly, pro rata, as the bottom ones; and they then score twice as many awards points for their members.
TABLE IV-Distribution of distinction awards analysed by type of hospital contract, England and Wales 1980

\begin{tabular}{|c|c|c|c|c|c|c|c|}
\hline & \multirow{2}{*}{$\begin{array}{l}\text { Number of } \\
\text { consultants }\end{array}$} & \multicolumn{5}{|c|}{$\begin{array}{c}\text { Percentage of } \\
\text { consultants with awards }\end{array}$} & \multirow{2}{*}{$\begin{array}{l}\text { Awards points } \\
\text { per } 100 \\
\text { consultants* }\end{array}$} \\
\hline & & $A+$ & A & $\mathrm{B}$ & $\mathrm{C}$ & $\begin{array}{c}\text { All } \\
\text { awards }\end{array}$ & \\
\hline \multicolumn{8}{|l|}{ Average: all } \\
\hline consultants & 13300 & 0.9 & $3 \cdot 3$ & $9 \cdot 5$ & $21 \cdot 7$ & $35 \cdot 3$ & $54 \cdot 1$ \\
\hline PGTH & 631 & 3.5 & $7 \cdot 4$ & $20 \cdot 0$ & $21 \cdot 2$ & $52 \cdot 1$ & $97 \cdot 4$ \\
\hline $\mathrm{AHA}(\mathrm{T}) \dagger$ & 5120 & 1.8 & 5.9 & $14 \cdot 4$ & 20.9 & 43.0 & $74 \cdot 6$ \\
\hline $\mathrm{RHA}+$ & 7210 & 0.3 & $1 \cdot 2$ & $5 \cdot 6$ & $21 \cdot 8$ & $28 \cdot 9$ & $37 \cdot 8$ \\
\hline \multicolumn{8}{|c|}{ Consultants aged $60-64:$} \\
\hline $\begin{array}{l}\text { PGTH } \\
\text { AHA(T) }\end{array}$ & $\begin{array}{r}48 \\
596\end{array}$ & $\begin{array}{r}22.9 \\
8.6\end{array}$ & $\begin{array}{l}20 \cdot 8 \\
17 \cdot 8\end{array}$ & $\begin{array}{l}41 \cdot 7 \\
25 \cdot 1\end{array}$ & $\begin{array}{l}10 \cdot 4 \\
25 \cdot 8\end{array}$ & $\begin{array}{l}95 \cdot 8 \\
77 \cdot 4\end{array}$ & $\begin{array}{l}247.9 \\
163.8\end{array}$ \\
\hline RHA & 810 & 1.4 & 4.6 & 16.9 & 43.8 & $66 \cdot 7$ & $94 \cdot 3$ \\
\hline
\end{tabular}

* $\mathrm{A}+=4$ points; $\mathrm{A}=3$ points; $\mathrm{B}=2$ points $\mathrm{C}=1$ point

+ These figures do not include about 1000 consultants employed in both AHAs(T) and RHAs. This group score close to those with AHA(T) contracts only. The AHA(T) figures include 201 consultants with contracts at both PGTHs and 
basis of anecdote and hearsay from a slanted selection of people whose qualification is that they have themselves had success in the system. The committees rarely have more than rudimentary and sporadic written information about the consultants in the region. Yet the work of most consultants will be largely unknown to the committee members, especially those of different specialties and districts.

Different scores of awards between groups of consultants may reflect genuine differences of talent or achievement. Such differences as might reasonably be tenable, however, are multiplied to levels of absurdity by the current system. Exaggeration of imbalances stems from the selection of committee members exclusively from award holders; they tend, inevitably, to share the mutual regard and sincere prejudices of those same senior colleagues who chose them. Thus each successive echelon of nominees must compound the bias of the groups who select them. This process might at least be curbed if the committees included the opinion of younger consultants who are not in the immediate running. A heavy representation of women is probably required to offset the current bias against them.

\section{Personal statement}

Since our first paper ${ }^{1}$ we have tried to master our anger and dismay and, in successive studies, to consider how things go wrong. We remind ourselves that most colleagues are fair minded. There is no Machiavellian plan, no crooked conspiracy. But we are disappointed to face finally that group allegiances and prejudices are stronger than rationality.

We have met support, argument, and hostility over the years; we have had our legs pulled. Much remains debatable, but we are back where we came in, with a batch of figures that we can only regard ironically in a rough and ready world. We should like the system abolished because it remains immutably unfair, divisive, and, in its secrecy, contemptible. No other profession would copy this system and consultants would gain respect by scrapping it-especially self-respect. Moreover, we suspect that the dangling carrot has helped to keep the salary of most consultants down.

We feel somehow saddled with this peculiar subject. We do also have other clinical interests which we write about from time to time, and we wish others would take this one over now. The injury to women is flagrant and calls for immediate correction.

We are grateful to officials at the Department of Health and Social Security for help in providing fresh information this year.

\section{References}

${ }^{1}$ Bourne S, Bruggen P. Examination of the distinction awards system. $\mathrm{Br}$ Med F $1975 ; \mathrm{i}: 162-5$.

${ }^{2}$ Bourne S, Bruggen P. Distinction awards for England and Wales 1977 observations and a look ahead. Br Med f $1979 ; \mathrm{i}: 638-9$.

${ }^{3}$ Bruggen P, Bourne S. Further examination of the distinction awards system in England and Wales. Br Med f 1976;i:536-7.

${ }^{4}$ Bruggen P, Bourne S. Third examination of the distinction awards system in England and Wales. $B r$ Med 7 1977; : $: 462-4$.

5 Bourne S, Bruggen P. Re-examination of the distinction awards system in England and Wales, 1976: the new advisory committees. Br Med $\mathcal{F} 1978$ i:456-7.

6 Bourne S, Bruggen P. Reviewing the distinction awards system in England and Wales, 1978 and 1979. Br Med F 1981;282:1005-7.

(Accepted 24 March 1982) recommended for awards. Though research is to be expected as part of the work of many academics and some laboratory workers, unusual effort by them may be recognised.

"Publication of medical papers of significance carries weight, but mere numbers of papers will not impress.

\section{MEDICAL ADMINISTRATION}

"Regular contributions to the work of hospital and other NHS committees deserves recognition, but not as substitute for good clinical or paraclinical work. To be deserving in the field of administration a community physician would have to contribute something more than his expected duty.

\section{Distinction}

"Here again precise definition of criteria for awards is not possible. To gain one of the small number of A awards a high standard is inevitably required. Awards for distinction might be recommended for: those who are evident leaders in a clinical or scientific field, including those with special skills; those who contribute new ideas of proven worth; those who are generally accepted as leaders of their profession in their region or in the country as a whole.

"An international reputation deserves respect, but is not established by a mere list of attendances at foreign meetings.

\section{Criteria for awards to community physicians}

"For a community physician to be recommended for an award his service or distinction must be of the same general standard as that required for an award in other disciplines, but the criteria will differ in some respects: as in the case of clinical specialties something more is needed than the ordinary service to the NHS which is the duty of any consultant, but more recognition will be given to effort and skill in medical administration or management activities; ability to co-operate with other clinical and community medicine specialists and to give effective advice to colleagues or authorities is to be expected; the successful introduction of new ideas or services is highly meritorious.

"For higher awards the same qualities of leadership as those set out above for other specialties would be expected. Awards are not given for seniority nor especially to holders of particular types of post."

\section{NAHA supports regional advisory arrangements}

The National Association of Health Authorities (NAHA) has said that it supports the objectives outlined in the DHSS's report on regional management arrangements. The report was produced by the Joint Working Group on Medical Advisory and Representative Machinery (2 January, p 64). The NAHA agrees with the recommendation to simplify the machinery. It agrees that the number of main committees should be restricted but disagrees with the recommendation of basing the composition of the committees on geographical representation. It thinks that that would create large committees in regions with many districts.
The Association foresees several problems arising from the establishment of one set of subcommittees to serve all three main committees, a further suggestion made in the report. Given the different functions of the main committees, the association thinks that such an arrangement would not adequately provide the specialty advice needed by all three committees. RHAs should maintain their present arrangement of subcommittees, whereby the number and type are determined by the individual needs of each main committee. 